\title{
Social Construction of Retirement among Retired Teachers in Makueni County
}

\author{
Annastasia Katee Musila ${ }^{1^{*}}$, Harrison Maithya ${ }^{2}$, JaminMasinde $^{3}$ \\ ${ }^{I}$ Department of Human and Social Development, School of Social and Development Studies, Technical \\ University of Kenya \\ ${ }^{2}$ Department of Sociology, Anthropology and Community Development, School of Education, Humanities and \\ Social Sciences, South Eastern University of Kenya \\ ${ }^{3}$ Department of Sociology and Psychology, School of Arts and Social Sciences, Moi University, Kenya
}

*Corresponding Author: Annastasia Katee Musila, Department of Human and Social Development, School of Social and Development Studies, Technical University of Kenya

\begin{abstract}
Retirement is a period that is associated with many problems ranging from physical, psychological to socio-economic ones. While the majority of research in Kenya has focused on the challenges of retirement, little is known about how retirees socially construct their retirement. This study, therefore, sought to examine how retired teachers in Makueni County socially construct their retirement in spite of the challenges associated with this period. The study was guided by the following theories: Social Construction by Berger (1966), Disengagement by Cumming and Henry (1961) and Life Cycle Perspective by Elder Jr (1960).The research used purposive and snow ball sampling techniques to sample 249 respondents of which 173 were males and 76 females. Questionnaires, face to face interviews and focus group discussions were used to collect both qualitative and quantitative data. Qualitative data was thematically coded and analysed through content narrative analysis while Statistical Package for the Social Science (SPSS) was used to analyse quantitative data. The study found that retirement is both a time to relax and engage in development activities as well as that of suffering and social-ridicule. The study therefore, concludes that retirement is constructed either positively or negatively depending on if the retiree had planned for it and invested for the future. The study recommends that employers need to continually train workers in preparation for retirement. In addition, retirees need maintain good social relations with others that pension should be paid in time.
\end{abstract}

Keywords: Retiree, Retirement, Social Construction, Relationships, Development.

\section{INTRODUCTION}

Retirement is a transition from being in occupation to other life options such as leisure, volunteering to help others or to engaging in business activities (Kleiber \& Linde, 2014). This is the time when one permanently leaves his or her job either due to official or personal reasons. There are two broad categories of retirement namely: mandatory/official and early/voluntary retirement (Teachers Service Commission, 2014). Mandatory retirement is the time that one is asked by the employer to stop working upon attaining the retirement age which ranges from 60years to 70years in many countries. Early or voluntary retirement is when a person chooses to retiree either due to health reasons or wishes to change his/her socio-economic lifestyle (Milligan, 2011;Were,2009). Retirement is thought to be a relatively new phenomenon in the world as it dates back to the 20th Century. Initially, workers were mostly employed in agricultural farms and were allowed to continue working till death. At old age, the workload would be adjusted to what one could manage given the state of his/her body and health due to ageing (Seattle Times, 2013).

Retirement period has been viewed in research as a problematic phase in one's life. It is a time when one's capability to earn may diminish by virtue of age or health issues (Kimani ,2008). According to Ejorueme (2012) and Tirindi(2012) old age has been associated with a myriad of problems that range from physical, mental, economic to social problems. Transition to retirement could lead to sudden loss, for example, in finances and identity as retirees are expected to stop working. Consequently, they have to learn to adjust to a different identity of not being employed and associated with their career title as well as adjusting to a time of not earning the usual monthly salary. Thus, retirees are expected 
to live with new statuses and different social identities as they try to align their lives to living with no occupation. According to Were (2009) Milne (2013)and Osborne (2012), retirement is also surmised to be a sign of stigma in many societies as it signifies that time of life that one is expected to be poor and his/her health deteriorates as a result of advancement in age (Taylor \& Earl, 2015; Smith \& Moen, 2004).

In spite of the difficulties associated with retirement, some retirees become more useful to their communities as they have free time and the autonomy to make decisions on the direction of their own lives (Zeliski, 2013). For example, some retirees link their communities with the government or nongovernmental organizations by identifying and implementing projects that benefit the community such as those in education or agricultural sectors. Furthermore, others offer their expertise whenever called upon to do so in different sectors of their communities, for example, religious organizations, schools, or community development. Some other retirees start projects that can be used as development models by their communities such as in farming or entrepreneurship. By being actively involved in different realms of their communities, these retirees construct their retirement positively.

According to Osborne (2012) and Ejionueme (2012) there are retirees who find their retirement as a period full of challenges, which include financial or health related. Such retirees construct their retirement negatively since they see it as time characterised by suffering, poverty, socialridule and brain wastage (Museya, 2014). It is against this backdrop that the current study investigated how the retired teachers in Makueni County socially constructed their retirement.

Retirement might be seen as a time for one to adapt to new conditions of life, setting new goals, and even psychological changes. Some retirees take time to have leisure since they are free from the strict job regulations of formal employment as such; they areat liberty to steer their lives on their own terms (Kleiber \& Linde, 2014; Wang, 2013). Psychologically, a retiree has to accept the reality that he or she is no longer waking up to report to work but is waking up free, to act as per his or her own programme. This thought can be scary to the people who are workaholics. Indeed, the fact that one may wake up and no particular office to go to can be a stressor. Those who held high positions might miss the big titles and the privileges that come with such offices. This is a period that calls for people to accept the change, think about the future and set new life goals (Milne, 2013; Norcross, 2009). The transition from employment to retirement can be palliated if one follows his/her passion or gifting in life away from his or her professional engagement.

Literature on retirement seems to bring out two contrasting views on how retirees construct retirement. Some retirees construct their retirement in a positive manner while others do so in a negative way. Those who look at it positively see it as a time to relax and move on to other income generating activities. This implies that those who embrace retirement are likely to move on with life in their retirement by engaging in various activities in their community. Retirees who regard retirement as a painful period may experience financial and social challenges. This group of retirees is likely to have negative feelings and lifestyles in their retirement. Thus retirees look at their retirement from different perspectives.

Retirement reality has both a subjective and objective side (Wallace, 2006). Subjectively is a question of how individuals perceive and behave in their retirement. For some retirees, it is a welcome status to be out of formal employment during which one has the freedom to decide when to wake up, to take breakfast or to undertake whatever activity he or she wishes to get involved in (Kleiber, 2014). For others, retirement may signify a painful period when one is thrown out of employment by the employer in this case the Teachers Service Commission, which is a government body with the mandate of employing public teachers in Kenya. Objectively retirement is that time that one is asked by the employer to vacate his or her job at attaining the mandatory retirement age. Retirement has been seen as covering two dimensions of people's lives that is the practical and psychological dimensions (Cohen \&Regev, 2012). Practically, retirement can be similar to career change as one may not be expected to work full time and would have the freedom to decide on how to steer his/her life thereafter. In the practical dimension of retirement, one needs to plan, learn, prioritize, network, and choose new directions. A retiree needs to focus on what he/she believes in and what he/she thinks is important to him/her. Psychologically, it is a time of engaging in a different life journey where there are possibilities of uncertainty, fear, anxiety and confusion (Nikolova\& Graham, 2014; Atchley, 1999; Osborne, 2012). Retirees may be confused initially, especially in making decisions on how to invest the lump sum money or where to get funds to educate their children for those whose children could 
still be in school by the time they retired. This paper therefore looks at how retired teachers in Makueni County socially construct their retirement.

\section{Materials ANd Methods}

The study on which this paper draws was conducted in Makueni County, which has six constituencies namely, Mbooni, Kilome, Kaiti, Makueni, Kibwezi West and Kibwezi East. The most highly populated constituencies are Makueni and Mbooni due to their proximity to Kilungu and Mbooni Hills respectively. Kibwezi West and East, Kaiti and Kilome have low population densities and are also low potential areas with poor soils (Mwangangi et al., 2012).

The study adopted a qualitative research design. The target population was retirees in Makueni County and sample for the study was drawn from retired teachers. The variations in the retirees' features were significant as retirees coping strategies were thought to be influenced by factors such as education level, income or social exposure. Teachers form a high percentage of the elite class in rural Kenya. They are respected by the other members of the society and act as role models in development activities.

The study used purposive sampling technique to identify mandatory or voluntary retired primary or secondary teachers in the study area. The study started by categorising the region in terms of the available political zones, particularly the constituencies for the purposes of getting respondents. The study covered four out of the six constituencies. This decision was arrived at because most of them were fairly homogenous in terms of demographics, physical features, and socio-economic activities and, therefore, representative. It was thus not necessary to visit all of them. Makueni and Mbooni constituencies were chosen for the study since they are the two most populated constituencies in the county. Secondly, the retirees' views on retirement and socio-economic activities in these two regions were expected to be different as Makueni is drier and hotter than Mbooni, which owes its cool climate to Mbooni hills (Government of Makueni, 2018). Kibwezi East and West were chosen for the study because they are the least populated constituencies in the county and are also the most dry (Makueni Development Plan, 2013). Retired teachers were identified through the help of contact persons who were either the area chief, a fellow retiree, a pastor, Quality Assurance Officials or head teachers.

A variety of data collection methods including in-depth interviews, questionnaires, observation, focus group discussions and key informants were used. The research applied qualitative content analysis procedure and simple quantitative data analysis. The former was applicable in the interpretation of the content of text data through a systematic classification process where the information gathered was coded through the identification of themes and patterns. In quantitative data analysis, tables were drawn to show the percentage of respondents' construction of retirement.

The study on which this paper is based employed the Social Construction theory of retirement by Berger(1966), Disengagement theory by Cumming and Henry (1961) and Life Cycle Perspective theory by Elder Jr (1960). The first theory is one of the phenomenological theories whose emphasis is on an individual and his/her conscious experiences. It talks about the lived experiences of the actors and what they make out of them depending on where they might socially be. That means the social lives of people and what they go through in their neighbourhood have an impact on how they interpret their situations and whether they think they are good or bad. This theory was thus relevant in looking at how retired teachers in Makueni County view their social world as retirees, as they interact with other people in the society.

Disengagement theory by Cumming and Henry (1961) stipulates that people disengage from their job roles and other social relationships as their abilities deteriorate with age. According to this theory, disembarking is a natural and accepted process as people age and start losing their ego energy (Ritz, 2012; Crossman, 2019). This theory is relevant to retirement as retirees have to withdraw from their professional responsibilities and pursue other roles in the society. A retiree in Kenya, for example, can spend his/her time in various ways. This is a state of re-engagement after retirement but not disengagement on a downward trolley, which is expected to culminate into death.

Life Cycle Perspective theory by Elder Jr (1960) proposes that people continue doing the things they have always done even in their old age (Hutchison, 2011). According to this theory, individuals have plans, make choices and undertake actions within the opportunities and constraints of their social worlds. This theory was relevant to this study in trying to discover the plans that the retirees had put 
in place for their retirement as well as the choices that they were executing One's views of retirement are likely to depend on his/her social environment (Mo wang et al., 2011). This may depend on his/her relationship with his/her family, whether he/she had invested for retirement or not. Those with good social-economic investments are more likely to find retirement enjoyable while those without such investments are more likely to find the retirement period as one full of misery and frustrations. Furthermore, the theory also talks about life transitions as contextually embedded, meaning that time for mandatory retirement is appointed. Through job policies, all civil servants are to retire at a given time; this is in spite of whether the retiree was working for the government or a private company. Nevertheless, each retiree maneuvers this change from being employed to being jobless depending on his or her constructed meaning of retirement.

\section{RESUltS AND DisCUSSIONS}

\subsection{Social Construction of Retirement}

Social construction of retirement by retired people refers to ways in which retirees look at their retirement based on the lived experiences that they go through in their communities. Retirees construe retirement either positively or negatively. Those with a positive view of retirement see it as a time of freedom during which they are able to relax and engage in other activities. Retirees who have a negative view see retirement as a time of socio-economic suffering.

\subsection{Positive Construction of Retirement}

Positive construction of retirement is reflected in the views of retirees that stress how beneficial the retirees think retirement is to them and the society while the negative view of retirement is construed in the fact that the retirees find their retirement a loss. This study revealed that $71 \%$ of the retirees thought they had more opportunities of freedom and happiness. This freedom enabled the retiree to rest from the teaching responsibilities and venture into other personal and socio-economic activities such as spending time with their families, farming, starting businesses or just having time to relax. This freedom of doing whatever one wished any time was thought of as having contributed to their being happy and relaxed. Freedom was also experienced by those who had leadership positions such as being school counsellors or games masters/mistresses or even the school head or principal. Such activities take a toll on one's time and energy. In stressing how energy sapping and time consuming the responsibilities mentioned were, one former male primary school head teacher gave the following narrative:

As a head teacher I had to wake up early daily because I was heading a school far from home and I needed to get there before the teachers and everyone else. Indeed, I was the main custodian of the office keys, meaning I would report early and leave late. But now since I am retired, I go to the farm or attend to other businesses whenever I feel like.

This was a clear indication of how retirement offered freedom by relieving the head teacher of the responsibilities of heading a school. Similarly, freedom was experienced in the fact that the retired teachers did not have to ask for permission from anyone to attend to their own duties. In stressing how she felt free to do whatever she deemed important for her, one female primary school retiree observed the following:

I am a member of several women groups such as merry go rounds, retiree forums as well as a church development committee. I used to train girls in netball, I still go to watch this game whenever I feel like without having to ask the head teacher or his deputy for permission.

This female retiree had benefitted in the fact that she does not have to consult the head teacher for permission to attend to any business or go anywhere. However, a minority of $3 \%$ felt that retirement gave them very little freedom. These were mostly people who still held leadership positions in their communities where they were expected to attend meetings as well as to make decisions. Others had investments that still called for their time and energy. These were mostly the former school heads and principals who were highly respected by their neighbours and looked upon to give them counsel in development or social activities. Therefore, although they were retired, they were still engaged in other affairs such as community leadership and representations in different forums, which included church or school management affairs. Freedom in retirement is thus experienced differently. For some, it is seen in as far as they do not have to oblige to the rules and regulations of their job even 
though in some communities this becomes the time that one is burdened by the demands of his/her community. For instance, both primary and secondary male retirees felt that their freedom had been curtailed because the society had burdened them with development responsibilities and political positions. The women on the other hand, were not engaged much with community leadership responsibilities but were more involved in social activities. Therefore, for most of them retirement led to freedom to socialize and engage in other activities away from the demands of being a teacher.

Positive view of retirement was evident among $63 \%$ of the retirees who had psychologically prepared themselves as they knew that at some point the government would send them home on retirement after they attain the retirement age. These are the retirees that had invested; therefore, retirement brought them the freedom to concentrate on their family businesses without the guilt of having neglected one's official responsibilities. Similarly, these retirees did not have resentment towards being retired as they had psychologically attuned themselves to the fact that retirement was an inescapable reality upon reaching the retirement age.

The following are some narratives of how retirees perceived the benefits accruing from retirement most especially freedom:

I feel less stressed because I do not have to answer to furious administrators like the Assistant Education Officer (A.E.O), currently known as Quality Assurance Officers, or the head teacher. I can plan my time without having to plead with anyone for permission to be away from work. Today, I go and come back as I please (A primary school male retiree).

A female primary school retiree who had health challenges narrated how the head teacher disclosed her condition to the other teachers. This subjected her to social stigma and emotional trauma, as her private life had become publicized. This disclosure obviously affected her performance hence she opted for early retirement though she had not made any prior plans to retire. This helped to reduce her stigma or working under duress. These views are in concord with those of Milne (2013) that retirement saves people from unfair treatment by harsh and insensitive bosses.

A different male retiree, a former principal who was engaged in several businesses such as book selling and real estate development observed:

I am fully enjoying my life doing what I like, making more money than I ever did as a school principal. I can choose to stay at home and go to collect money at end of the month. I can work over the phone and ensure that things run smoothly in the construction site. I cannot think of going back to teach because of the demands of the young students and teachers. Those fellows have a lot of energy, let them sort themselves out but if they need my counsel, I will gladly give them.

To this former principal, retirement meant happiness and freedom where there is flexibility of what he is able to do on a daily basis as well as a relief from the demands of the responsibilities of heading a school. These views are in consonance with those of Weiss (2005) (cf. Kleiber\& Linde, 2014) who observed that participants in his research considered gains of retirement to include freedom to engage in other activities, and freedom from the hustles of work-related pressures.

A total of $51 \%$ of the respondents held the view that retirement had given them freedom to disengage from teaching and pursue personal interests in other areas such as farming, business or volunteering their services in various capacities to the society. These views agree with those of Zeliski (2013) and Landis (2012) that retirees are happy as they enjoy the freedom of decision making. Retirees are better off looking at retirement as a good thing that gives them the opportunity to implement their goals without being controlled by the structures of job regulations. In emphasising this fact, a female respondent and a widow gave the following narrative:

After retirement I found myself busy doing things for others including my own children who were relaxing in Nairobi with their families, hence I decided to take charge. I called a family meeting, informed each of them to take their cattle to their own homesteads so that when their shamba (farm) boys run away that does not become my bother any more. Now I can wake up when I want without any worries about which goats or cows have not been grazed. My pension and the few investments that I made with "mzee" (old man) coupled with the support that I get from my children are enough for my upkeep. Therefore, life is easy for me as I choose where to go, when or which "mwethya" (social group) to join. 
Similarly, a male respondent who was a quality assurance officer at the time of his retirement had this to say:

Retirement has helped me a lot for I had some business, which I was able to expand after I retired. I have also been a role model to my neighbours in farming as I have over five wells and I irrigate various crops where the small market business women (mama mboga) come and purchase farm produce like green maize, sukuma (kales), tomatoes, among others to sell in the local market. My neighbours have also borrowed this idea since we are on a river line so those whose land is adjacent to mine are also doing the same kind of farming. This has boosted the living standards of families nearby. Apart from business and farming, I have been given several political appointments. I am currently the County Chairman of one of the political parties. Until recently I was a member of the Transport and Licensing Board for 6 years. All these achievements could not have been realised if I was still teaching.

One key informant, a pastor, observed the following in stressing how retirement seemed to have accorded the retirees freedom that was deemed beneficial to the society:

Retired teachers are very instrumental in the development activities of the community. In church, we use them to pass information to the church members. Teachers are gifted in communication, record keeping and mobilising others. Since retirees are considered to be free, they are appointed in various positions in the church committees. They are the best in being masters of ceremonies during church or other functions. In deed if I am away, I usually depend on one 'mzee', a former teacher to preach and organize the church service on my behalf.

Additionally, freedom to venture into other activities was evident as two of the nine retired principals were elected as MCAs (Members of county assemblies) where they continued to serve the community through representing them in the political arena.

Retirement construction was also considered in line with how the retirees thought it had affected their social relationship with others as reflected in the table below:

Table1: Kind of social relationship with others after retirement

\begin{tabular}{|l|l|l|l|l|l|}
\hline $\begin{array}{l}\text { Level of relationship after } \\
\text { Retirement }\end{array}$ & $\begin{array}{l}\text { Spouse } \\
(\boldsymbol{\%})\end{array}$ & $\begin{array}{l}\text { Children } \\
(\boldsymbol{\%})\end{array}$ & $\begin{array}{l}\text { Siblings } \\
(\boldsymbol{\%})\end{array}$ & $\begin{array}{l}\text { Neighbour } \\
(\boldsymbol{\%})\end{array}$ & $\begin{array}{l}\text { Associates } \\
(\boldsymbol{\%})\end{array}$ \\
\hline Excellent & 33.9 & 28.8 & 22.3 & 15.4 & 17.5 \\
\hline Very good & 33.5 & 35 & 28.3 & 26.3 & 29.6 \\
\hline Good & 27.3 & 31.7 & 43.8 & 51.7 & 47.1 \\
\hline Bad & 2.6 & 3.3 & 3.9 & 5.8 & 5.4 \\
\hline Very bad & 2.6 & 1.2 & 1.7 & 0.8 & 0.4 \\
\hline
\end{tabular}

$\mathrm{N}=249$.

The majority of the respondents $(94 \%)$ both male and female who had worked in either primary or secondary school levels said that their relationship with others ranged from good to excellent. This is because after retirement they had more time for the family and did not have the pressures of work. Therefore, they were likely to have become more relaxed hence able to socialize more with others.

The study also sought to find out if the retirees had married after retirement or engaged extra marital affairs and only five male retirees who were former primary school teachers said they had engaged in extra marital affairs while none had married a second. This was confirmation that they had good family relationships as people enter a second marriage or have extra marital affairs to escape from unhappy marital unions. In stressing the value of good marital relations, one male former principal who taught away from Makueni County said the following:

It was not difficult to fit back at home as a wife can make or destroy the home. I have a wonderful wife who takes care of all of us, pushing us to be the best we can. Currently I am pursuing PhD in business. I failed my proposal defence, but she keeps nagging me to pick it up. So, what I am saying is she took care of the investments and represented me in the village functions. Therefore, I owe my success to her. On my part I also ensured I visited them weekly as much as possible during my working period.

Another male primary school retiree said: 
I used to drink a lot and get sick often too, but two years to my retirement my wife who is a nurse decided with the doctor who used to treat me to tell me lies that if I did not stop drinking, I would die in less than a year's time. That threat worked and I stopped drinking forthwith. I allowed my wife to take charge of my salary and pension thereafter. She built our permanent home, educated our children and we have also invested in plots. Right now, our last born is in form four and we also take care of my late sister's children.

Similarly, a female primary retiree whose husband was not working but used to take care of their home and she, the financial needs (something that is not common in traditional African societies) was very grateful to her husband and children. She had this to say:

You know my husband was not as educated as me so he is the one who took care of our children when they were small. He did the farming and ensured that our farm was full of all manner of fruits; we never bought vegetables like Sukuma (kales) and nyanya (tomatoes). We maintained a small garden, which he would fetch water to irrigate. When I look back, I am very proud of his dedication to making our family prosper as it did then. Today, all our children are working and married they always ensure that we have food and other necessities as they have arranged that one of them visits us on a monthly basis.

To this female retiree, life would not have been the same if she did not have a good relationship with her husband. This is because he accepted to take roles that are traditionally assigned to women such as taking care of the home, children and farming. She was also happy that her family was in good terms to the extent that her children were taking care of her and her husband.

On the same note, a different female primary school retiree said the following in appreciating her children:

'My children have been very kind to me and I owe them for the kind of life I am leading today including this kiosk that I am running. They are the ones who developed this plot of land for me. They also market for me the mango fruits, I normally send them through the matatus then they pick, pack and sell to their friends at work. This is beneficial because the people who come to buy directly from us five shillings while at Nairobi, they sell at Ksh25to $k \operatorname{sh} 30^{\prime \prime}$.

This information shows that this particular retiree has a good relationship with her children, otherwise they would not have bothered to support her by putting up a kiosk to keep her busy and selling mangoes from her farm to their colleagues.

The above narratives illustrate how good social relationships benefited some of the retirees. Social support is also crucial in transitioning from one stage of life to another. Therefore, the retirees who had close relationships with their families found the transition into retirement smooth. This cordial relationship enabled a retiree to have self-confidence and high self-esteem in spite of his/her age or having exited from a salaried working status. Social support also offers social capital from which people are able to draw emotional and practical support, information as well as companionship.

The relationship with neighbours and former colleagues was reported to be good as only $6.8 \%$ of the respondents said they had bad relations with their neighbours. Good neighbourhood was enhanced as retirees took part in various social welfare groupings within their villages, church committees, women merry-go-rounds or male investment groups. Life cycle perspective posits that people continue doing whatever they were used to before even in retirement. This view was true as most of the retirees had good social relations in their families and neighbourhood as they continued engaging in the same social welfare groups that they were members of.

In relation to the retirees having generally good to excellent social relationships with others, one male former principal said that he was the chairman of a group of 20 families with over 200 members represented. Another former male primary school teacher respondent also said he belonged to a couples' welfare group, which started over twenty years ago. He observed that they visited one family per month in this group and they challenge each other to engage in activities geared towards development. Some of the activities that they encouraged members to venture in included digging terraces and buying bulls or cows so that by the time of their next visit to that household, they would get a good report of the economic progress made. This group ensured that the members educated their children. He indicated that his own children were doing well with some of them working abroad. This 
group was planning to launch a bank in Wote town by the time of this research. Therefore, good neighbourliness is also seen in the fact that majority of the retirees were playing various roles in the community and churches even in small ways as reading out the church programs or announcements during the service.

One key informant, a chief, was in agreement with the foregoing that the retired teachers had been of benefit to the community and his leadership. This is because they easily comprehend issues hence are able to convince the other members of the community on the importance of NGOs or CBOs to the development of their localities. The chief also said that in settling disputes like those between school administrators and parents the retirees came in handy as they would provide mature constructive comments toward resolving such disputes.

One primary school female teacher said that she was playing various roles in the community, such as being the chairlady of Kenya Women Finance Trust (KWFT) as well as a District Church Council. Another primary school male retiree was the chairman of Action Aid Programme in Wote, an organization that helps women and supports needy children in the County. Others mentioned that they were members of farming groups or political groupings. These engagements point to the fact that many of the respondents have good social relationships with their neighbours. For instance, one to chair various community committees, it was through a majority vote, which was only possible if one was popular and trusted by the other group members.

In supporting the position that the retirees had good relationships with others, one female key informant, who is engaged with an NGO group, Women Empowerment Enterprise, had only praise for the retiree teachers in their group. This is a group that has assisted Women of African Inland Church (A.I.C) to buy plastic water tanks. Here the women get an additional tank for every tank that they purchase. This is similar to another group in Mbooni, named "Kwauaitungimuongo", a slogan which means removing water jerrican from their backs. This particular NGO helps women to purchase water tanks for rain water harvesting so that they may reduce the burden of carrying water on their backs. The key informant who is the coordinator of the African Inland Church women group indicated that the group had 18 women and two of them were retirees. She narrated the following in relation to how important the retirees were to the group:

There are two retirees in this group and they are the ones who help in the running and organization of the group. One of them is the Chairlady who mobilises the other group members and sets the pace for them. The other members kind of follow whatever "Mrs" (the term commonly used for a married female teacher) says. The other retiree in the group is elderly and plays the role of teaching and preaching to the group especially on lessons to do with how the 'Ndiwa' (widows) ought to conduct themselves.

From the foregoing explanations it is evident that retired teachers are in good social relationships with their neighbours and are positively engaged in their respective communities.

The male focus group also highlighted that even though they would not say that they have a bad relationship with their former colleagues, their interests have changed on the basis of what they prioritize. Teachers who are still in employment have priorities different from those of the retirees. As a result, the two groups engage on different platforms such as community development matters, unlike before when they would engage majorly on school matters. The concerns of the retirees were noted to be very different from those of the teachers still in office. For instance, it was argued that those still teaching would be talking of school matters while the retiree would be keen on investment, security, politics or health matters. The fact that the interests of the retirees and those of the teachers have changed has also led to the initiation of welfare groups for only retired teachers in various parts of Makueni County. During such forums, the retirees discuss their common challenges and also use that opportunity to socialize and link up with their old friends.

The idea of retirees joining social groups is thought to work positively for them as a research done in England revealed. Joining social groups that are organized with scheduled activities promotes the health and wellbeing of retirees in retirement (Steffens et al., 2016). These views resonate with those of Zelinski (2013), that social groups give retirees identity and offer a remedy for the lost connectivity with their former colleagues in retirement. However, not all the retirees had fond memories of being retired. There are those who see their retirement from a different and negative angle as discussed in the next section. 


\subsection{Negative Construction of Retirement}

Retirement was considered to have brought pain and suffering amongst the retirees in various ways. It was viewed as a time that the retirees were subjected to degradating status and socio-economic ridicule. This perception was held by a group of retirees who had not invested and who found it difficult to accept their retirement status. These retirees had relatively low education levels and taught in primary schools; their salaries were small and they could not invest for the future. These retirees had children in school and in some cases they had to take care of their siblings. They were thus opposed to the idea of being retired arguing that retirement was a waste of human brains and a degrading time where people are forced to go home to suffer in poverty.

One male respondent, a primary school retiree while stressing this position suggested that 'people should be allowed to work like drivers work until they can work no more.' For him, being told to retire left him feeling that he still had a lot of energy to go on working, which would have benefitted his pupils.

In supporting the argument that retirement is a disappointing period, another female primary school retiree observed thus,

Retirement period is a time to embarrass people who were respected in the community. This is the time that people run away from you. Casual labourers stop passing by your home because they fear you might not pay them after they work for you. Your relatives stop picking your phone calls. Sometimes even children may visit you very erratically because they know you have no money since they are aware that there are cases of delay in pension payment.

This female retiree obviously did not have fond memories of the first years of her retirement before she received her pension as she remembered how her friends and family used to avoid her. These people felt she had no money and was likely to borrow from them or ask them to work and wait for the pay, which would be made at a later date. To support the notion that retirement was a period of disgrace to the retirees, one male retiree narrated the following:

At the time that you are asked to retire you are more knowledgeable and experienced. In fact, as a leader you work with more ease since by this time you have seen it all in management, made bad and good decisions, learnt group and personnel dynamics, as well as people's preferences. You are more endowed with team building skills and conflict resolution skills. If it were possible, the government should have the new employee work under supervision of the outgoing one for at least a year so that the new workers may benefit from the wealth of information that the outgoing ones have especially in the case of school heads (a former principal)

Another male retiree also indicated that mandatory retirement leaves ex-workers feeling rejected. $\mathrm{He}$ had this to say:

Retirement to some extent makes one experience a sense of being taken advantage of. One feels that he or she has been treated as an industrial raw material where the waste is disposed of after processing of the valued goods (a primary school male retiree).

Although people must disengage from employment as a matter of policy at some point in time, it is obvious that for some retirees, retirement is not something to be happy about. The retiree feels unwanted by the employer.

About $40 \%$ of the respondents asserted that they were not adequately prepared for retirement. Various reasons were advanced. For some, their children were still in school and they needed more time and resources to finish educating them. For others, they had not finished personal projects such as construction of permanent houses while others felt that the retirement notice was short. These reasons led to the retirees arguing that, to them, being sent home on mandatory retirement was in a way similar to condemning them to poverty for the rest of their lives. Thus, they wished they were allowed time to continue working in order to finish their unfinished business, especially that of educating their children. Upon retirement, they had no money to pay school fees hence they borrowed to educate their children. $s$ Failure to do this meant that they suffer the embarrassment of going to explain themselves to school administrators to allow their children to be in school while they looked for money to pay the fees.

The women focus group discussion had similar views that women face many challenges when they are not earning a salary. According to them, retirement made them to be looked down upon by their 
family members. They argued that in their view husbands believe that the demands of their wives become increased when the latter have no salaries of their own. The children also start looking at their retired mother with suspicion because they think that their mother is always out to demand for financial support. They also claimed that to get casual workers becomes an impossibility as neighbours treat retirees with suspicion fearing that they may work for them and not get their due pay. Thus, according to them, their neighbours gave them an impression that a retired woman cannot be trusted to honour her promises especially in regard to financial matters. This perception strains the relationship between the women retirees and their neighbours. A research done by Mutual (2015) in USA came up with similar findings that women have higher levels of stress than men in retirement.

These views generally resonate with those of Ejionueme (2012) who observed that retirees face many challenges such as financial and emotional ones. Retirement is seen as a time when one has to adjust his/her lifestyle to live on a lower pay as the pension is usually lower than the salary. It is also a time when the health of a person starts to deteriorate as a result of aging. These views are also in line with those of Landis (2012) who observes that retirees have many concerns, which include finances, health, boredom, relationships and other emotional challenges such as feeling lonely and worthless. However, this study did not find the retirees in Makueni County to have the challenge of boredom and loneliness as majority of them were engaged in community welfare groupings where they served in different capacities. Serving in such community committees boosted their self-esteem as they continued to feel useful and productive.

\section{CONClusion}

This paper concludes that retirees construct their retirement positively and negatively depending on the social relationships that they have with their families and community members, the kind of planning that they had put in place especially in the area of saving. Retirees who have been engaged positively with their immediate family members find it easy to retire as their homes provide comfort in retirement. These retirees are likely to have educated and disciplined their children such that the same children are able to support them in their old age. Getting involved in community affairs is also beneficial for the retiree as community members offer the company and close ties that are lost upon retirement as one no longer has close relations with colleagues at work. The community is a resource as the retirees get an opportunity to continue feeling accepted and useful through offering different services to the community, for instance, volunteer services, training opportunities or leadership of group organizations. On the other hand, retirees who may have neglected their families while working, or failed to get involved in community activities find their retirement a disgrace and a painful period. It is important that workers build networks, do not neglect their families and community at the expense of their work since one cannot remain in employment forever.

The three theories guiding this research were found to be relevant. The social construction theory posits that people construe life events as per their interaction with the society. In this study retirees constructed their retirement positively or negatively depending on how they felt accepted and appreciated by their community. The disengagement posits that people disengage from their work as their energy levels go down due to old age, though it is a fact that the teacher retirees had retired from teaching, there are those who accepted their retirement and devised other means of surviving both socially and economically. These ones disengaged to re-engage. The life cycle perspective was found applicable in this study as the retirees were found to have different views of retirement. This means that each person has the autonomy to make his or her decisions and deal with the consequences. For example, retirees who accept their retirement move on with life positively engaging in activities that are constructive and beneficial to themselves and others while those who chose not to accept their retirement end up being unhappy as they are always bitter with their former employer and society, they consider them unfair. Thus retirement can be a time to relax and enjoy life as long as one planned and built close ties with others or it can be a painfully frustrating experience.

\section{REFERENCES}

[1] Atchley, R. C. (1999) Continuity and Adaptation in Aging: Creating Positive Experiences, Baltimore, Maryland, USA: John Hopkins University Press.

[2] Berger, P. L. and Luckmann, T. (1966) The Social Construction of Reality: A Treatise in the Sociology of Knowledge, London, United Kingdom: Penguin Group.

[3] Cohen, J. \&Regev, I. (2012) Expectations and Impacts of Retirement Preparation Programs, Tel Aviv, Israel: Tel Aviv University Press. 
[4] Nikolova, M. and Graham, C. (2014) Employment, Late-Life-Work, Retirement and Well-Being in Europe and the United States, IZA Journal of European Labor Studies 20143:5.

[5] Crossman, A. (2019) Disengagement Theory: An Overview and Critique, New York, USA: Thought Co, Available at: https://www.thoughtco.com/disengagement-theory-3026258

[6] Ejionueme L. K., Ugwoke S. C., Etonyeaku E. A. C.\&Anyanwu J. I. (2012). Principals' Perception of Coping Strategies for Retirement in Enugu State., US-China Education Review, 3(2), 997-1001.

[7] Government of Makueni (2018) County Annual Progress Report, 2018, Wote, Kenya: Department of Finance \& Socioeconomic Planning, County Government of Makueni.

[8] Hutchison, E.D. (2011) A Life Course Perspective: Chapter One from Dimensions of Human BehaviourThe Changing Life Course, Thousand Oaks, California, USA: Sage Publications.

[9] Kleiber, D.A. and Linde, B.D. (2014) The Case for Leisure Education in Preparation for Retirement Transition, Journal of Park and Recreation Administration, Vol.32, Number 1, pp.111-128.

[10] Kleiber, D.A. (2012) Leisure Activities in Later Life, Athens, Greece: University of Georgia. Milligan, K.S. \& Wise, D.A (2011) Lives with Fewer Safety Nets, NBER Working Paper No. JEL No. H3, H5, J1, J2, Retrieved From: https://www.nber.org/papers/w14647.pdf.

[11] Kimani, E. (2008) World Vision Abundant Wisdom for Living, Nairobi, Kenya: Word Alive Publishers.

[12] Landis, A. (2012) When I Retire: The Fastest, Easiest Way to Make Your Retirement Fun, Fulfilling, and Significant, California, USA: Create Space Independent Publishing Platform.

[13] Milligan, K.S. \& Wise, D.A (2011) Lives with Fewer Safety Nets, NBER Working Paper No. JEL No. H3, H5, J1, J2, Retrieved From: https://www.nber.org/papers/w14647.pdf

[14] Milne, D. (2013) The Psychology of Retirement: Coping with the Transition from Work, Hoboken, United States: John Wiley \& Sons.

[15] Osborne, J. W. (2012). Psychological Effects of the Transition to Retirement, Canadian Journal of Counselling and Psychotherapy. 46. (2) Pp 1-13

[16] Seattle Times (2013) A Brief History of Retirement: It's A Modern Idea, Seattle, Washington, United States of America: Seattle Times Publications.

[17] Smith, D. B., \& Moen, P. (2004). Retirement Satisfaction for Retirees and Their Spouses: Do Gender and The Retirement Decision-Making Process Matter? Journal of Family Issues, 25, 262-285.

[18] Taylor, P. and Earl, C. (2015) Making a Case for Older Workers, Management Review, Volume 27, No. 12, pp14-28, ISSN-0935-9915.

[19] Tirindi, C.K. (2012) Aging and Retirement in Kenya: Focus on Aging and Retired Teachers Under the Teacher Service Commission, Nairobi, Kenya: Kenyatta University.

[20] TSC- Teachers Service Commission-Kenya (2014) Code of Conduct and Ethics Arrangement of Regulations, Available at: https://www.kenyaschoolforintegratedmedicine.org/wp-content/uploads/2014/ 09/Code-of-Regulations-for-Teachers

[21] Wallace, R., \& Wolf, A. (2006). Contemporary Sociological Theory: Expanding the Classical Tradition, London, United Kingdom: Pearson.

[22] Wang, M., \& Shi, J. (2014) Psychological Research on Retirement, Annual Review of Psychology, 65, 209 233.

[23] Were, M. (2009) The Concept of Retirement Age, Nairobi, Kenya: Retirement Benefits Authority

[24] Zelinski, E.J. (2013) How to Retire Happy, Wild, and Free, Essex, United Kingdom: Vision International Publishing.

Citation: Annastasia Katee Musila, Harrison Maithya, JaminMasinde. "Social Construction of Retirement among Retired Teachers in Makueni County" International Journal of Research in Sociology and Anthropology (IJRSA), vol 5, no. 3, 2019, pp. 9-19. doi: http://dx.doi.org/ 10.20431/2454-8677.0503002.

Copyright: (C) 2019 Authors. This is an open-access article distributed under the terms of the Creative Commons Attribution License, which permits unrestricted use, distribution, and reproduction in any medium, provided the original author and source are credited. 